\title{
Routine Primary PCI; Whether and When Necessary for the Management of NSTEMI-An Evidence Based Evaluation
}

\author{
Irtiza Hasan ${ }^{1,2 *}$, Tasnuva Rashid ${ }^{3}$, Md. Harun Ur Rashid Bhuiyan ${ }^{4}$ \\ ${ }^{1}$ Cardiology, University of Canterbury Christ Church University, Kent, UK \\ ${ }^{2}$ Internal Medicine, The University of Edinburgh, Edinburgh, UK \\ ${ }^{3}$ Department of Epidemiology, The University of Texas HSC at Houston, School of Public Health, Texas, USA \\ ${ }^{4}$ Clinical \& Interventional Cardiology, Z.H. Sikder Cardiac Care \& Research Centre, Dhaka, Bangladesh \\ Email: ${ }^{*}$ irtiza.hasan@icloud.com
}

Received 7 November 2015; accepted 5 December 2015; published 8 December 2015

Copyright (C) 2015 by authors and Scientific Research Publishing Inc.

This work is licensed under the Creative Commons Attribution International License (CC BY).

http://creativecommons.org/licenses/by/4.0/

(c) (i) Open Access

\begin{abstract}
Non ST elevated myocardial infarction (NSTEMI) accounts for a significant portion of the hospitalizations due to acute coronary syndromes worldwide and is posing a huge challenge towards the health care cost globally. This signifies the need for proper triage and management stratification for the best utilization of the health care resources. Primary Percutaneous Coronary Intervention (PCI) with early revascularization is a new emerging invasive technique and application of this technique is increasing tediously among the clinicians. However, the current body of evidences is divided between the efficacy, need and critical timing of PCI compared to conservative management in the treatment protocol for NSTEMI. A review of trials done comparing the early use of PCI versus conservative management indicates inconsistent finding with strong evidence towards early use of PCI in moderate to high-risk NSTEMI patients.
\end{abstract}

\section{Keywords}

Non ST-Elevation Myocardial Infarction (NSTEMI), Percutaneous Coronary Intervention (PCI)

\section{Introduction}

The clinical phenomenon that occurs due to acute coronary blockage and resultant ischemia in the myocardium is called Acute coronary syndrome (ACS), which is differentiated primarily based on severity into unstable an-

*Corresponding author.

How to cite this paper: Hasan, I., Rashid, T. and Bhuiyan, Md.H.U.R. (2015) Routine Primary PCl; Whether and When Necessary for the Management of NSTEMI-An Evidence Based Evaluation. World Journal of Cardiovascular Diseases, 5, 343-350. http://dx.doi.org/10.4236/wjcd.2015.512040 
gina (UA), non ST elevated myocardial infarction (NSTEMI) and ST elevated myocardial infarction (STEMI) [1] [2]. These are pathophysiologically related to each other and commonly caused by instability and rupture of atherosclerotic vulnerable plaques [3] [4]. Only about one fourth of the ACS cases are due to STEMI and the rest majority being either UA or NSTEMI [5]. Some recent studies have found that about $54 \%$ of the ACS patients admitted to the hospital have NSTEMI [5]. It has also been found that most of the NSTEMI patients tend to be older with multivessel disease, poor LV function and have higher mortality rate (31\%) compared to STEMI patients (21\%) [5]. These facts highlight the need of evidence-based approach for the preventive and risk stratified management of the type specific coronary diseases. In this write-up, we will focus mainly on the evidence-based management of NSTEMI with particular emphasis on coronary angiography (with a view to revascularization).

\section{NSTEMI}

NSTEMI can be defined as a development of heart muscle necrosis following an acute interruption of blood supply due to subtotal occlusion of coronary vessels (e.g. atheromatous plug rupture, dissection, vasculitis, etc.) without any elevation of ST-segment in electrocardiogram (ECG), and can be demonstrated by an elevation of cardiac enzymes (CK-MB, troponin I \& T) in the blood [6] [7].

NSTEMI mostly presents with typical anginal pain (constricting, tightening or heavy in character, usually located in the center of the chest, but may radiate to neck, jaw, shoulder, back, and arms) at rest or on minimal exertion but may also present with breathing difficulty, sweating, palpitation or even without any significant symptoms [6]. As there is subtotal coronary artery occlusion, NSTEMI is understandably less severe than STEMI (complete coronary occlusion) [6].

Long standing exposure to the risk factors (like hyperlipidemia, hypertension, smoking, hyperglycemia, abdominal obesity etc.) results in the formation of atherosclerotic plugs [8]. When a vulnerable atherosclerotic plug ruptures, it results in thrombus formation, which causes subtotal occlusion of major coronary arteries or total occlusion of minor coronary arteries causing necrosis of partial thickness of the myocardium. This is the most common mechanism for NSTEMI (shown in Figure 1). Inabout 35\% to $75 \%$ cases of UA or NSTEMI, there is evidence of a coronary thrombus occluding the infarcted artery, which occurs in more than $90 \%$ of the cases of STEMI [9].

\section{Management of NSTEMI}

Diagnosis of NSTEMI is mostly made by clinical history, ECG changes and assessment of cardiac enzymes. Treatment of NSTEMI involves urgent in-hospital care by some general and specific means. Medical treatment focused on stabilization of plaque and prevention of progression and prevention of subsequent future events as well as treating the symptoms. On the other hand, revascularization by either percutaneous coronary intervention (PCI) or coronary artery bypass grafting (CABG) aims to re-establish effective coronary blood flow, leading to improvement of myocardial ischemia and its manifestations [10].

\section{Medical management}

Early supportive measures include: 1) bed rest with continuous monitoring by ECG; 2) inhaled oxygen therapy—if oxygen saturation (\%) is low; 3) analgesia (usually opioid analgesics); 4) beta blockers \& nitrates; 5) calcium channel blocker (diltiazem, verapamil) for patient having pain in spite of having full dose of nitrate \& beta blockers or who have a contraindication to beta blockers; 6) angiotensin converting enzyme (ACE) inhibitors/ angiotensin receptor blockers (ARBs) - to treat hypertension or if there is LV dysfunction; and 7) statins (irrespective of cholesterol level).

Specific medical measures encompass: 1) antiplatelet therapy and 2) antithrombin therapy [11].

\section{- Antiplatelet therapy}

1) Aspirin-reduces mortality, $300 \mathrm{mg}$ single loading dose is given unless contraindicated (major bleeding risk or hypersensitivity), clopidogrel should be considered if the aspirin is contraindicated;

2) Clopidogrel-after assessing the adverse cardiovascular risk $300 \mathrm{mg}$ single loading dose is given to all patients along with aspirin and continues for a month. In low risk patients, clopidogrel should be discontinued 5 days before CABG, whereas it can continue before CABG in intermediate to high-risk patients;

3) Glycoprotein IIb/IIIa inhibitors (tirofiban, abciximab, or eptifibatide)-mostly given to the patient with 


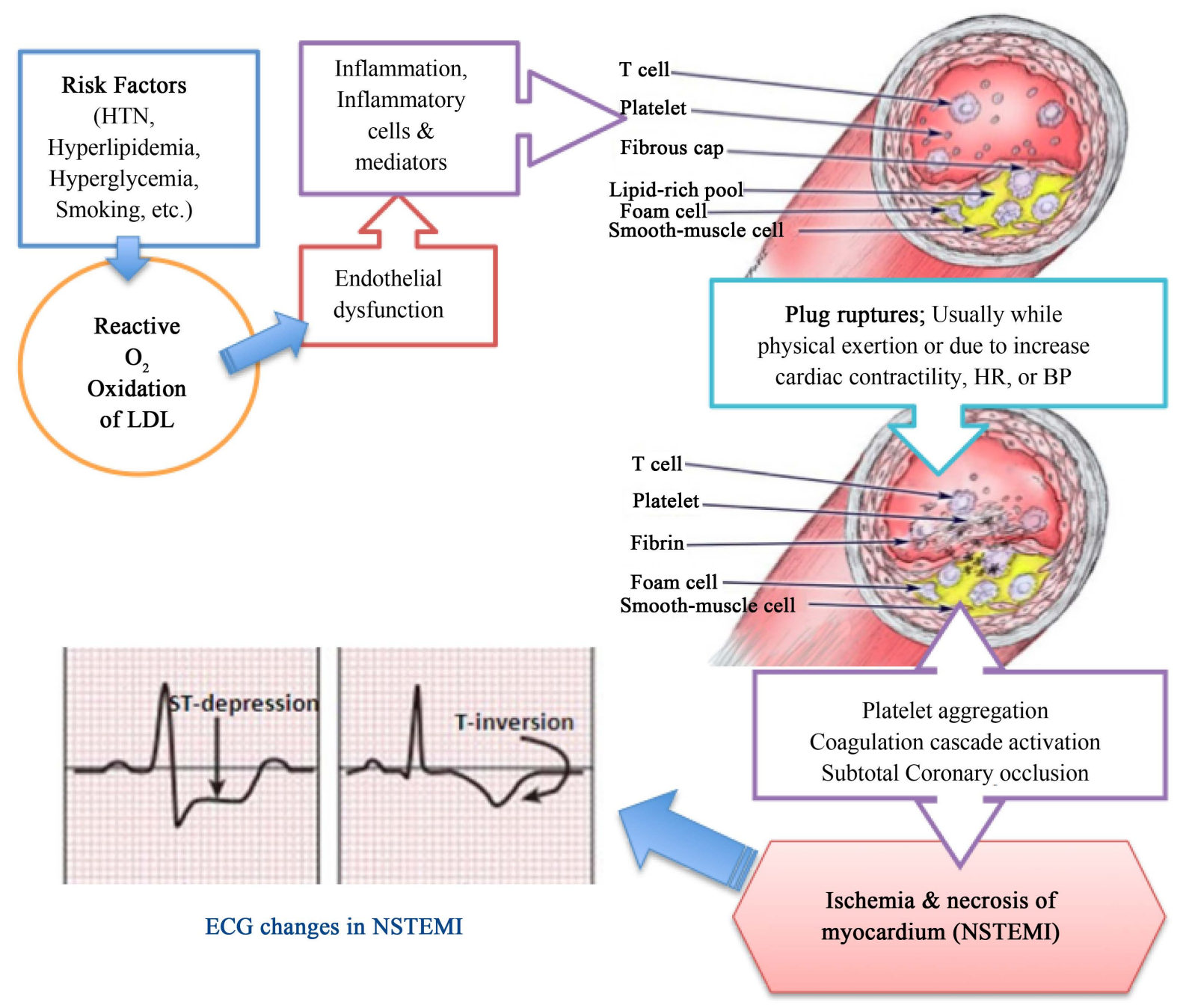

Figure 1. Pathophysiology of NSTEMI.

intermediate to high cardiovascular risk; eptifibatide or tirofiban can be considered for the patient who will undergo angiography within 96 hours of hospital admission and abciximab considered in adjunct to PCI.

\section{- Antithrombin therapy}

It considered based on patients weight, age, renal function and history of bleeding complications. If there is plan for coronary angiography within 24 hours of admission and there is no significant renal impairment (creatinine above 265 micromoles/liter); unfractionated heparin (dose adjusted based on clotting function) should be consider, otherwise Fondaparinux given as an alternative. Systemic unfractionated heparin (50 - 100 units/kg) can also be given in the cardiac catheter laboratory to patients receiving Fondaparinux who are undergoing PCI. As an alternative to combination of heparin plus GP inhibitors; bivalirudin can be consider for the patients with intermediate or higher risk of adverse cardiovascular events not received a GPI or Fondaparinux yet and scheduled for angiography (with PCI if needed) within 24 hours of admission.

\section{Coronary angiography and revascularization}

It is an emerging invasive treatment strategy with a view to early revascularize. In this review we will look at the evidences for and against the routine use of early PCI as compared to conservative medical management.

\section{Evidences for Routine PCI in NSTEMI}

Coronary Angiography is an X-ray imaging of the coronary vessels and is a gold standard for the diagnostic evaluation of the coronary vessels in terms location and severity of atherosclerotic plaques, anatomy of coronary 
arteries and providing guideline for the need of therapeutic interventions (medical management, PCI with stent placement or CABG) [12]. In spite of all the benefits, there is a significant risk (1 in 100 to 1 in 1000) of various complications ranging from minor bleeding to life threatening complications like heart attack, stroke, renal failure and death [13]. As such there is critical balance between the two to guide the treatment strategies. With the evidence based medicine approach, the use of coronary angiogram is limited to the cases where the benefit outweighs the risks [4]. Based on this principle, two pathways of treatment emerged for the NSTEMI patientsEarly-invasive strategy versus early conservative strategy. In early invasive strategy, all patients without any contraindication undergo coronary angiography followed by revascularization (if needed) within 4 to 24 hours of hospital admission [4]. On contrary, in the early conservative strategy medical therapy is initiated for all patients and coronary angiogram is reserved for those with risk factors like advanced age, history of MI, previous revascularization, heart failure related complications and so on [4].

However, with the advancement of science, modification of clinical techniques, use of drug eluting stents and novel drugs there has been a continuous modification in the guidelines and protocols related to the use of PCI in NSTEMI. Starting from early nineties there has been various large-scale clinical trials worldwide to detect the critical point between early invasive and early conservative strategies as shown in evidence Table 1.

\section{Discussion}

Based on the above-mentioned evidences it is seen that the data is not consistent throughout. Some of the trials like FRISC II, TACTICS-TIMI18, VINO, RITA-3, ISAR-COOL found that in moderate to high risk groups the benefit of early intervention overweighs the early conservative therapy in terms of better overall prognosis, reduced risk of subsequent hospitalization and need of multiple anti-angina medication [4] [14]-[17]. In contrary, trials like TIMI-III B, ICTUS trial, ABOARD showed no significant difference was seen between the two groups. Of the studies which compared immediate versus delayed PCI, most of them found no difference in the timing of PCI with one (ABOARD) finding slightly higher complications with immediate PCI [18]. ISAR-COOL study, which looked at anti-thrombotic pretreatment of PCI, found that early intervention had lesser complication. However, all the trials varied by their patient population, age group, cardiac risk factors, ECG findings, inclusion and exclusion criteria, use of PCI techniques, choice of medical therapies and so on. Hence, the current trials cannot be generalized to the other populations. As such there is a need for more properly designed and generalizable trials to better characterize the treatment protocols.

According to NICE guideline, risk assessment should be done following initial management using GRACE or TIMI Score [11]. As per AHA guideline, the high risk indicators for NSTEMI include: 1) Patients with recurrent angina/ischemia at rest or with low-level activities despite intensive anti-ischemic therapy; 2) Recurrent angina/ischemia with CHF symptoms, an S3 gallop, pulmonary edema, worsening rales, or new or worsening mitral regurgitation; 3) High-risk findings on noninvasive stress testing; 4) Depressed LV systolic function (e.g., EF< 0.40 onnoninvasive study); 5) Hemodynamic instability or angina at rest accompanied by hypotension; 6) Sustained ventricular tachycardia; 7) PCI within 6 months and 8) Prior CABG.

The high to moderate risk NSTEMI patients should be considered for early invasive therapy using PCI or CABG [11]. Intravenous GP IIB/IIIA should be given to all patients undergoing PCI [22]. Early conservative medical therapy should be considered in low risk patients followed by angiography and revascularization for those who are resistant to medical therapy [22]. The indication for PCI includes multivessel coronary diseasewith suitable coronary anatomy, normal LV Function and without diabetes; one to two vessel coronary disease without significant proximal LAD blockage and with a large area of viable myocardium and high-risk criteria on noninvasive testing [22]. Thus, current evidences favor the use of conservative management in low risk patients and early invasive management for moderate to high-risk NSTEMI patients.

Though in this paper we tried to evaluate all the trials and meta-analyses related to the early PCI for NSTEMI, however there might be other related trials, which were beyond the scope of this paper.

\section{Conclusion}

The evidence obtained from different trials does not provide a strong generalizable background for the use of early PCI in all NSTEMI cases. Further clinical trials are needed to better justify the use and timeline of PCI in 
Table 1. Evidence table for coronary angiography \& revascularization (PCI) in NSTEMI [4].

\begin{tabular}{|c|c|c|c|c|c|c|}
\hline Trial (year) & $\begin{array}{l}\text { Coronary } \\
\text { events }\end{array}$ & Population & Treatment & Endpoints & Result & Conclusion \\
\hline $\begin{array}{l}\text { TIMI-IIIB trial } \\
\text { (1994) [4] }\end{array}$ & $\begin{array}{l}\text { Unstable } \\
\text { Angina } \\
\text { (UA) }\end{array}$ & $\begin{array}{c}1473 \text { men and } \\
\text { women; } \\
\text { Age } 21 \text { - 79; } \\
\text { have ECG } \\
\text { changes of } \\
\text { undocumented } \\
\text { CAD }\end{array}$ & $\begin{array}{l}\text { Early invasive } \\
\text { (PCI) vs. early } \\
\text { conservative } \\
\text { therapy. PCI done } \\
\text { within the first } 6 \\
\text { weeks especially } \\
\text { in the first } 48 \\
\text { hours. }\end{array}$ & $\begin{array}{l}\text { Composite of } \\
\text { death, MI or } \\
\text { abnormalities on } \\
\text { an exercise } \\
\text { stress test. }\end{array}$ & $\begin{array}{c}\text { No significant } \\
\text { difference in } \\
\text { composite endpoint. } \\
\text { Significant } \\
\text { difference in length } \\
\text { of initial } \\
\text { hospitalization } \\
\text { (p = } 0.01 \text { ), incidence } \\
\text { or re hospitalization } \\
\text { within } 6 \text { weeks } \\
\text { (p }<0.001) \text { and } \\
\text { number of days of } \\
\text { re-hospitalization } \\
(p<0.001)\end{array}$ & $\begin{array}{l}\text { Either therapy } \\
\text { is appropriate } \\
\text { for patient } \\
\text { management }\end{array}$ \\
\hline $\begin{array}{l}\text { FRISC II trial } \\
\text { (1999) [14] }\end{array}$ & NSTEMI & $\begin{array}{l}2457 \text { patients } \\
\text { from } 58 \\
\text { Scandinavian } \\
\text { countries. }\end{array}$ & $\begin{array}{c}\text { Early invasive } \\
\text { versus early } \\
\text { conservative } \\
\text { treatment with } \\
\text { placebo-controlled } \\
\text { long-arm LMWH } \\
\text { (deltaparin). } \\
\text { Coronary } \\
\text { angiography done } \\
\text { within } 7 \text { days of } \\
\text { randomization }\end{array}$ & $\begin{array}{c}\text { Composite } \\
\text { endpoint of } \\
\text { death or MI. }\end{array}$ & $\begin{array}{l}\text { After } 6 \text { months, the } \\
\text { incidence of MI or } \\
\text { death was } \\
\text { significantly lower } \\
\text { in early-invasive } \\
\text { group (p = 0.03). } \\
\text { Decrease in angina } \\
\text { symptoms and } \\
\text { hospital } \\
\text { readmission. } \\
\text { Highest benefit for } \\
\text { the high-risk } \\
\text { patients with ST } \\
\text { depression in ECG } \\
\text { and troponin T } \\
\text { levels was at least } \\
0.03 \text { pg/L. At } 5 \\
\text { years follow up the } \\
\text { composite endpoints } \\
\text { were lower in early } \\
\text { invasive group } \\
\text { (p = 0.009) }\end{array}$ & $\begin{array}{l}\text { Short-term } \\
\text { follow up } \\
\text { shows early } \\
\text { invasive } \\
\text { therapy better } \\
\text { than early } \\
\text { conservative. } \\
\text { The } 5 \text { years } \\
\text { follow up } \\
\text { showed } \\
\text { sustained } \\
\text { benefit of early } \\
\text { invasive } \\
\text { therapy in } \\
\text { moderate to } \\
\text { high-risk } \\
\text { patients. }\end{array}$ \\
\hline $\begin{array}{c}\text { TACTICS-TIM } \\
\text { I } 18 \text { trial (2001) } \\
{[4]}\end{array}$ & NSTEMI & $\begin{array}{l}2220 \text { patients } \\
\text { aged } 18 \text { or more } \\
\text { were randomly } \\
\text { selected based } \\
\text { on ST changes } \\
\text { in ECG with } \\
\text { raised cardiac } \\
\text { biomarker. }\end{array}$ & $\begin{array}{l}\text { Early-invasive } \\
\text { treatment strategy } \\
\text { (routine coronary } \\
\text { angiography and } \\
\text { if needed } \\
\text { revascularization } \\
\text { within } 4 \text { to } 48 \\
\text { hours of hospital } \\
\text { admission) versus } \\
\text { a more } \\
\text { conservative } \\
\text { strategy (medical } \\
\text { management and } \\
\text { coronary } \\
\text { angiography only } \\
\text { in patients with } \\
\text { spontaneous or } \\
\text { inducible } \\
\text { Ischemia). All } \\
\text { patients received } \\
\text { aspirin, heparin \& } \\
\text { tirofiban. }\end{array}$ & $\begin{array}{l}\text { Composite of } \\
\text { death, nonfatal } \\
\text { MI, and } \\
\text { re-hospitalization } \\
\text { for ACS at } 6 \\
\text { months }\end{array}$ & $\begin{array}{l}\text { Primary end point is } \\
\text { significantly lower } \\
\text { in early invasive } \\
\text { group ( } \mathrm{p}=0.025) \text {. } \\
\text { Intervention } \\
\text { superior if Troponin } \\
\text { T positive } \\
(\mathrm{p}<0.001) \text { and } \\
\text { TIMI score }>3 \text {. }\end{array}$ & $\begin{array}{l}\text { The benefits } \\
\text { of the } \\
\text { early-invasive } \\
\text { strategy was } \\
\text { greatest only in } \\
\text { medium- and } \\
\text { high-risk } \\
\text { patients, with } \\
\text { elevated cardiac } \\
\text { troponin T } \\
\text { levels and ECG } \\
\text { demonstrating } \\
\text { ST-segment } \\
\text { change or a } \\
\text { TIMI risk score } \\
\text { of at least 3. In } \\
\text { other cases } \\
\text { there was not } \\
\text { any significant } \\
\text { difference } \\
\text { between the } \\
\text { groups. }\end{array}$ \\
\hline
\end{tabular}




\section{Continued}

$\begin{array}{ccc}\text { The VINO } & & \begin{array}{c}\text { based on } \\ \text { Study (2002) }\end{array} \\ \text { [15] } & \text { NSTEMI } & \begin{array}{c}\text { inclusion (ECG } \\ \text { change of ST } \\ \text { depression) and } \\ \text { exclusion } \\ \text { criteria. }\end{array}\end{array}$

$\begin{array}{ccc}\text { [16] } & \text { UA or } & \text { of mean age 62 } \\ \text { and } 38 \% \\ \text { women }\end{array}$

ISAR-COOL trial (2003) [17]

ICTUS trial
(2007) [18]
UA with NSTEMI or elevated cardiac troponin $\mathrm{T}$

\section{Multicenter trial of 1810 patients and $38 \%$ women}

1200 patients from 42 aged 18 to 80 years with inclusion criteria of

NSTEMI and elevated cardiac troponin

$\mathrm{T}$
137 patients were included from 10 centers criteria.
Early intervention versus conservative strategy. The antithrombin agent in both groups was enoxaparin.
First day Angiography/ angioplasty group versus early conservative group (medical treatment followed by angiography if recurrent MI)

$$
\begin{gathered}
\text { Six month mortality } \\
(\mathrm{p}<0.03) \text { or } \\
\text { non-fatal } \\
\text { reinfarction } \\
(\mathrm{p}<0.02) \text { was } \\
\text { significantly lower } \\
\text { in the first day } \\
\text { coronary } \\
\text { angiography group }
\end{gathered}
$$

At 4 months, 9.6\% of patients in early intervention group endpoints of combined rate of death, non-fatal myocardial infarction, or refractory angina at 4 month. The other endpoint was a combined rate of death or non-fatal MI at year 1 versus $14.5 \%$ of patients in

conservative group died or had MI or had refractory angina. Most of the difference was due to reduction in refractory angina. The rate was similar for both groups at 1 year.
First day coronary angiography followed by angioplasty reduces mortality and reinfarction in

NSTEMI

patients

Early intervention is better than conservative approach in NSTEMI patients mainly due to halved refractory angina cases and no increase in rate of death or MI
Anti thrombotic pretreatment for 3 to 5 days 410 patients admitted to 2 tertiary care center with symptoms of unstable angina with NSTEMI or elevated cardiac troponin $\mathrm{T}$

preceding coronary angiography versus early intervention of pretreatment. Antithrombotic included Iv unfractionated following 6 hours heparin, aspirin, clopidogrel and IV tirofiban

Early invasive strategy, including early routine

$$
\text { PCI and }
$$

revascularization when appropriate, versus selective invasive strategy, where PCI was

done if the patient had refractory

angina or history of CAD and other exclusion criteria's recurrent ischemia
Frequency of death, MI or re-hospitalization after 1 year.

Follow up was done at 4 year
$11.6 \%$ of Group receiving prolong anti thrombotic pretreatment had primary endpoint compared to $5.9 \%$ of group receiving early intervention.
Early intervention with intense anti thrombotic pretreatment has a better outcome compared to the group receiving prolong pretreatment with anti thrombotic
At the end of 1 year no difference

between the groups with respect to primary endpoint. Similar results were seen at the end of 4 year.
Early invasive strategy not better than selective invasive strategy. 


\section{Continued}

$\begin{array}{ccc} & \text { Multi-center } & \\ \text { trial conducted } & \\ \text { in } 3 & \\ \text { high-volume } & \\ \text { centers with } & \\ \text { PCI facilities. } & \\ & 142 & \\ & \text { patients }>21 & \text { Immediate PCI } \\ \text { OPTIMA trial } & \text { years of age } & \text { versus delayed } \\ \text { (2009) [20] } & \text { with no } & \text { PCI (24 to 48 } \\ & & \text { hours) } \\ & \text { contraindication } & \\ & \text { to PCI and } & \\ \text { fulfilling one of } & \\ \text { the } 4 \text { criteria's } & \\ \text { including raised } & \\ \text { troponin T, ST } & \\ \text { depression, } & \\ \text { CAD and risk } & \\ \text { factor for CAD } & \end{array}$

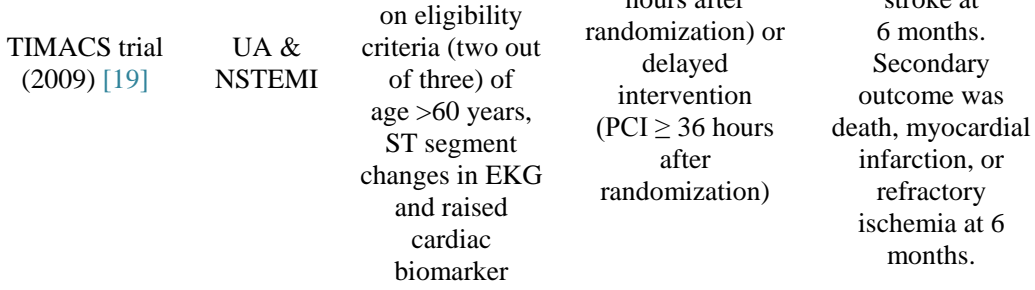

ABOARD trial (2009) [21]
NSTEMI
352 patients with NSTEMI

$$
\begin{aligned}
& \text { Multi-center } \\
& \text { trial with } \\
& \text { enrollment of } \\
& 3031 \text { patients } \\
& \text { selected based } \\
& \text { on eligibility } \\
& \text { criteria (two out } \\
& \text { of three) of } \\
& \text { age }>60 \text { years, } \\
& \text { ST segment } \\
& \text { changes in EKG } \\
& \text { and raised } \\
& \text { cardiac } \\
& \text { biomarker }
\end{aligned}
$$

Multi-center

facilities.

admitted at 13

high-volume

centers in

France. death, non-fatal
The primary

outcome was a

composite of

death, MI or

stroke at

6 months.

Secondary

infarction, or

schemia at 6

months.

The primary endpoint was a composite of MI or unplanned revascularization, at 30 days. Following discharge patients were followed up at 30 days and 6 months.

\section{The reduction in the primary outcome was not significantly different between the two groups $(p=0.15)$. There was a relative}

At 30 days, the

$$
\begin{gathered}
\text { The primary end } \\
\text { point was peak } \\
\text { troponin level } \\
\text { during } \\
\text { hospitalization. } \\
\text { Secondary } \\
\text { endpoint was the } \\
\text { composite of } \\
\text { death, MI or } \\
\text { urgent } \\
\text { revascularization } \\
\text { at } 1 \text { month } \\
\text { follow-up. }
\end{gathered}
$$
reduction of $28 \%$ of secondary outcome in early intervention group compared to delayed intervention $(p=0.003)$ especially in high-risk patients. incidence of primary endpoint was $60 \%$ in group with immediate PCI compared to $39 \%$ in group receiving delayed PCI ( $\mathrm{p}=0.004)$.

The incidence of MI was significantly higher in the group with immediate PCI $(p=0.005)$. The observed difference at the end of 30 days was preserved at 6-months' follow-up.

Early intervention was better to delayed intervention in reducing the rate of secondary outcome of death, MI or refractory ischemia especially in high-risk patients.

PCI for high-risk patients with NSTEMI should be delayed for at least $24 \mathrm{~h}$ after hospital admission

Both primary and secondary endpoints did not differ much between the two strategies
For patients
with NSTEMI
there is no
difference in
occurrence of
MI when
treated with
immediate
invasive vs.
invasive
therapy
scheduled on
the next day.

NSTEMI. The trials so far provided a basis for the use of PCI only in high to moderate risk NSTEMI patients.

\section{References}

[1] Antman, E., Bassand, J.-P., Klein, W., et al. (2000) Myocardial Infarction Redefined-A Consensus Document of the Joint European Society of Cardiology/American College of Cardiology Committee for the Redefinition of Myocardial Infarction: The Joint European Society of Cardiology/American College of Cardiology Committee. Journal of the American College of Cardiology, 36, 959-969. http://dx.doi.org/10.1016/S0735-1097(00)00804-4

[2] Apple, F.S., et al. (2007) National Academy of Clinical Biochemistry and IFCC Committee for Standardization of Markers of Cardiac Damage Laboratory Medicine Practice Guidelines: Analytical Issues for Biomarkers of Heart Failure. Circulation, 116, e95-e98. http://dx.doi.org/10.1161/CIRCULATIONAHA.107.185266

[3] Naghavi, M., et al. (2003) From Vulnerable Plaque to Vulnerable Patient a Call for New Definitions and Risk Assess- 
ment Strategies: Part I. Circulation, 108, 1664-1672. http://dx.doi.org/10.1161/01.CIR.0000087480.94275.97

[4] Sami, S. and Willerson, J.T. (2010) Contemporary Treatment of Unstable Angina and Non-ST-Segment-Elevation Myocardial Infarction (Part 2). Texas Heart Institute Journal, 37, 262.

[5] Homoud, M.K. (2008) Coronary Artery Disease. Tufts-New England Medical Center, 1-13

[6] NSTEMI (2014) http://nstemi.org/

[7] UpToDate (2014) Classification of Unstable Angina and Non-ST Elevation Myocardial Infarction.

[8] Yusuf, S., Hawken, S., Ôunpuu, S., et al. (2004) Effect of Potentially Modifiable Risk Factors Associated with Myocardial Infarction in 52 Countries (the INTERHEART Study): Case-Control Study. The Lancet, 364, 937-952. http://dx.doi.org/10.1016/S0140-6736(04)17018-9

[9] Libby, P. (2001) Current Concepts of the Pathogenesis of the Acute Coronary Syndromes. Circulation, 104, $365-372$. http://dx.doi.org/10.1161/01.CIR.104.3.365

[10] Nakamura, M. (2010) Angiography Is the Gold Standard and Objective Evidence of Myocardial Ischemia Is Mandatory if Lesion Severity Is Questionable. - Indication of PCI for Angiographically Significant Coronary Artery Stenosis without Objective Evidence of Myocardial Ischemia (Pro)-. Circulation Journal: Official Journal of the Japanese Circulation Society, 75, 204-210; Discussion 217.

[11] Gray, H.H., Henderson, R.A., de Belder, M.A., Underwood, S.R. and Camm, A.J. (2010) Early Management of Unstable Angina and Non-ST-Segment Elevation Myocardial Infarction: Summary of NICE Guidance. Heart, 96, $1662-$ 1668.

[12] Clinic, M. (2014) Coronary Angiogram. http://www.mayoclinic.org/tests-procedures/coronary-angiogram/basics/definition/prc-20014391

[13] NHS (2014) Cardiac Catheterisation and Coronary Angiography—Risks. http://www.nhs.uk/Conditions/CoronaryAngiography/Pages/Risks.aspx

[14] Lagerqvist, B., et al. (2006) 5-Year Outcomes in the FRISC-II Randomised Trial of an Invasive versus a Non-Invasive Strategy in Non-ST-Elevation Acute Coronary Syndrome: A Follow-Up Study. The Lancet, 368, 998-1004. http://dx.doi.org/10.1016/S0140-6736(06)69416-6

[15] Špaček, R., et al. (2002) Value of First Day Angiography/Angioplasty in Evolving Non-ST Segment Elevation Myocardial Infarction: An Open Multicenter Randomized Trial. The VINO Study. European Heart Journal, 23, $230-238$. http://dx.doi.org/10.1053/euhj.2001.2735

[16] Fox, K., et al. (2002) Interventional versus Conservative Treatment for Patients with Unstable Angina or Non-STElevation Myocardial Infarction: The British Heart Foundation RITA 3 Randomised Trial. The Lancet, 360, 743-751. http://dx.doi.org/10.1016/S0140-6736(02)09894-X

[17] Neumann, F.-J., et al. (2003) Evaluation of Prolonged Antithrombotic Pretreatment (Cooling-Off Strategy) before Intervention in Patients with Unstable Coronary Syndromes: A Randomized Controlled Trial. JAMA, 290, 1593-1599. http://dx.doi.org/10.1001/jama.290.12.1593

[18] Hirsch, A., et al. (2007) Long-Term Outcome after an Early Invasive versus Selective Invasive Treatment Strategy in Patients with Non-ST-Elevation Acute Coronary Syndrome and Elevated Cardiac Troponin T (the ICTUS Trial): A Follow-Up Study. The Lancet, 369, 827-835. http://dx.doi.org/10.1016/S0140-6736(07)60410-3

[19] Mehta, S.R., et al. (2009) Early versus Delayed Invasive Intervention in Acute Coronary Syndromes. New England Journal of Medicine, 360, 2165-2175. http://dx.doi.org/10.1056/NEJMoa0807986

[20] Riezebos, R.K., et al. (2009) Immediate versus Deferred Coronary Angioplasty in Non-ST-Segment Elevation Acute Coronary Syndromes. Heart, 95, 807-812. http://dx.doi.org/10.1136/hrt.2008.154815

[21] Montalescot, G., et al. (2009) Immediate vs Delayed Intervention for Acute Coronary Syndromes: A Randomized Clinical Trial. JAMA, 302, 947-954. http://dx.doi.org/10.1001/jama.2009.1267

[22] Braunwald, E., et al. (2000) ACC/AHA Guidelines for the Management of Patients with Unstable Angina and Non-ST-Segment Elevation Myocardial Infarctiona Report of the American College of Cardiology/American Heart Association Task Force on Practice Guidelines (Committee on the Management of Patients With Unstable Angina). Journal of the American College of Cardiology, 36, 970-1062. http://dx.doi.org/10.1016/S0735-1097(00)00889-5 